\title{
COMPARATIVE ANALYSIS OF INFORMATION PRESERVATION AND SECURITY IN THE PAST, PRESENT AND FUTURE
} ARU OKEREKE EZE ${ }^{1}$, UGOJI FRANK-GODRIC CHIDUBEM ${ }^{2}$

\author{
${ }^{1-2}$ Department of Computer Engineering \\ College of Engineering, \\ Michael Okpara University of Agriculture, Umudike \\ Umuahia, Abia State \\ Nigeria
}

\begin{abstract}
Information flows like fishes flow through the sea; this presents abundance opportunities for people to steal data making information security a necessity. Whether Information and records are paper, photographic, digital or audiovisual, they will deteriorate over time. The lifespan of this information and records will depend on how they are preserved and managed throughout their entire lifecycle; this makes information preservation another necessity. This paper is aimed at analyzing as well as comparing the ways in which information is preserved and secured in the past, what is like today and what is going to be in the near future. The descriptive survey research methodology was adopted in which questionnaire was used to capture data that made it easy to ascertain the levels of information preservation and security in the past, today and also estimated what it will be in the future. Based on the analysis made in this work, it is shown that in the past, information preservation and security was as low as $15.5 \%$. In the present, people are becoming more conscious of information security and preservation, skyrocketing the value to $33.1 \%$. This work also predicted that information security and preservation will be better in the near future with a takeoff value of $51.4 \%$. This work therefore concludes that information preservation and security is progressively increasing as information users are becoming very conscious.
\end{abstract}

Key words: Information, security, Preservation, policies, resources, libraries.

\subsection{INTRODUCTION}

Over the years, technology has rapidly evolved and with these advances, there is high demand for more sophisticated security measures to secure information as well as an advance means of preserving the information. Before the evolution of computers, information were kept mainly as paper records and are accessible by a few authorized individuals but as technology advances, the use of computer grew and this results to allowing large number of people access the information. Faced with the growing danger of loss of valuable information which determines the world's legacy of knowledge, identity, history and values of man, the need for more security measures and advance ways of preserving information for present and future generations becomes a necessity. Advance in technology has brought about digitization of information as well as giving room for information to be encrypted to safeguard the information from unauthorized individual for future use.

\subsection{SURVEY OF RELATED WORK}

Preservation refers to the set of activities that aims at prolonging the life of a record with little or no change to the original information as possible. Preservation also involves all the managerial and financial considerations including storage, accommodation provision, staffing levels, policies, techniques and methods involved in preserving information resources and the information contained in them. It is an aspect of the management of the library. Its objective is to ensure that information resources of any kind survive in an accessible and useable form for as long as it is wanted (Popoola, 2003) ${ }^{[1] .}$

Preservation is applied to safeguard information from decay and deterioration. Long before now, librarians have seen the need to preserve their information and information resources. This has engaged the thoughts and actions of many librarians from the earliest times which made them realized the need to actually preserve information.

According to Isah (2003) no librarian of today can shy away from the fact that 
"Information world" stands the imminent risk of losing so much of its valuable written heritage through the over increasing deterioration of information resources ${ }^{[2] . ~ N w i y e n w a ~(2000) ~ d i d ~ n o t ~ s k i p ~ w o r d s ~ w h e n ~ h e ~ s t r e s s e d ~ t h e ~ g r e a t ~ n e e d ~ f o r ~ a ~ w e l l ~}$ established document repair and conservation units in Africa because in his view, with the exception of air pollution, all agents which cause paper damage such as acid, heat, humidity, light, fungi, insects, pests, rodents, normal wear and tear and people are more pronounceable in the continent than elsewhere ${ }^{[3]}$.The value of information resources was clearly stated by the International Federation of Library Associations and Institutions (2003) .it states that:

"In no circumstances should information resources be regarded as additional luxury materials but rather they should be considered as necessary components in a fully integrated library services. In developed countries the provision of information resources and their associated equipments might be regarded as of greater importance than any other things because the level of literacy, oral and visual communication is essential" [4].

Notwithstanding the fact that school libraries play an important role in promoting students' education and preservation of cultural heritage, they were very often neglected (Matangira, 2003) ${ }^{[5]}$. However, the major objective of libraries is to facilitate access to collections of information as well as preserve the information for future generations.

The aim of Information Security is to protect the valuable resources of an organization which include; the hardware, software and skilled people. Applying then right security measure enables the organization to meet its business objectives or mission such as protecting its physical and financial resources, reputation, legal position, employees and other tangible and intangible assets. Information systems security begins with both the people within the organization and the people that interact with the system, intentionally or otherwise and also ends with them as well. The end-users who try to access the information which the security professionals are trying to protect could be the weakest link in security chain. Therefore, security administrators should try their possible best to reduce the levels of risk caused by end users and in addition, create more acceptable and supportable security profiles. These measures, together with appropriate policy as well as adequate training can improve the performance of end users and also result in a more secured information system.

\subsection{Elements Of Information Security}

Thomas R. Peltier (1977) in his work provided guidelines for effective Information Security Management. He postulated as follows:

i. Information protection should hold up business objectives or mission of enterprise. It is worthwhile to create Information Security Officer Post to hold up enterprise security.

ii. Information protection is a fundamental element for necessary care.

iii. Information protection must be cost-effective, that is, Implementation of controls must be proposed which is necessary in other to confirm that a significant risk exists.

iv. Information security responsibilities and accountabilities should be made very clear. This means that the information security policy should be able to identify the responsibilities and roles of all employees.

v. Owners of systems have information protection responsibilities within the own organization.

vi. Information protection requires a complete and an integrated approach ${ }^{[6]}$.

\subsection{RESEARCH METHODOLOGY}

The research Design is an exploratory study to investigate, analyze and also compare the levels of information preservation and security in the past, present and in the near future. Through the use of questionnaire, data was collected from the targeted organizations (National library, Imo State) and population. It was, therefore, descriptive survey research which brings out quantifiable information from the sample. For descriptive survey research design, the most suitable research instrument is a questionnaire. Input from the respondents was captured through the use of Questionnaires. The questionnaires consists of closedended and some few open-ended questions for ease of analysis. Questionnaires gave respondents the freedom of expression to enable them express their views or opinion and also make suggestions while maintaining anonymity $(\mathrm{Gay}, 1976){ }^{[7] .}$

\subsection{THE PAST, PRESENT AND FUTURE OF INFORMATION PRESERVATION AND SECURITY}

Preservation refers to the set of activities that aims at prolonging the life of a record with little or no change to the original information as possible. Information security involves the practice of preventing unauthorized access, use, disclosure, disruption, modification, recording or destruction of information. Relevant data, enhancement of cultural value and improvement of access are also important for preservation. When considering preserving and securing information for the future, we must learn to consider the past. Managing Threats Individually is no Longer Feasible based on the large Volume of Security Gaps That Exist and also faced with lots of weaknesses across the IT infrastructures leaves security personnel at a disadvantage. According to Gartner (2016), enterprises often make the mistake of implementing a reactive, rather than pro-active approach to information security $^{[8]}$. They usually depend on blocking techniques which have been proven to be ineffective. The greatest challenge in 
information preservation and security today is how to manage the large volume, velocity, and complexity of data. The need for information preservation and security has been around ever since the evolution of information.

\subsection{INFORMATION PRESERVATION AND SECURITY IN THE PAST}

In the past, information was preserved and secured in the public libraries, archival repository and museums. In public libraries, limited, tax-driven funding can often interfere with the ability for public libraries to engage in extensive preservation activities. Materials are more easy to replace than to repair when damage or worn out. Public libraries usually try to tailor their services to meet the needs and desire of people. Archival facilities focus particularly on scarce and fragile materials. Archives are usually available to a lot of public and private library facilities as a substitute to destroying older materials. Items such as photographs or items that are out of print can be preserved in archival facility more easily. Museums are very important place for preserving and securing information. Print materials, arts and other objects are often preserved and secured there. However, since most holdings are much more fragile or possibly corrupted, conservation may be more necessary than preservation. This is common in art museums. In many ancient societies, appeals to heavenly protectors were used to preserve and secure books, scrolls and manuscripts from insects, fire or even decay. The largest security concern was at the point of access of information. People can find their ways into libraries, museums or archives in the pretense to search for information but end up stealing valuable information. The level of preservation and security of information then was very low as a result of the unavailability of better preservative and security measures.

\subsection{INFORMATION PRESERVATION AND SECURITY TODAY}

Today, with the invention of computer and other electronic format, information preservation and security took a new dimension. Digitization and encryption is now the watch ward but they did not completely rule off the use of library, museums and archives for preserving information. Digitization refers to digital preservation of information. It is the process of converting analog materials into digital form through scanning and saving it in digital format. Through this process, information is better preserved and more secured than when is in analog form in which fire, water or decay can damage it and makes it useless. The introduction of network computing gave people the opportunity to seek ways to gain access to phone lines connected to computers so as to be able to steal sensitive information thereby making hacking a serious threat to security. With the emergence of computer and the popularity of using the internet, security has become its own business. Anyone with the knowledge of how to work with the computer could break into it and gain access to information which is a bridge of security. Hacking mainly takes place on computer that is connected on the internet; however, computers that are not connected can also be at risk. Increased information security problems comes from many sources including the expanded use of information system, the internet, e-mail applications and the adoption of Microsoft products. In order to secure terminals, passwords and multiple layers of security, protections were added to devices. Criminal prosecution, firewalls and antivirus software has served as a restrain to hackers but did not stop hackers who were skilled and bold enough to break into computer networks. Sequel to this, information security and preservation experts realized that the best way to secure information is through the process of encryption, which makes the information unreadable to the visible eye and if hacked become useless to the hacker. The encryption process offer high sense of security in which information can be protected and preserved properly.

\subsection{INFORMATION PRESERVATION AND SECURITY IN THE NEAR FUTURE}

Digitization seems to be one of the promising areas for future preservation and protection of information. Based on the latest report released by the Digital preservation coalition (DPC), it reviles that Portable Document Format (PDF) is one of the best format to preserve information and ensure their survival for the future. The report reviews PDF and the newly introduced $\mathrm{PDF} /$ Archive format as the potential solution to the problem of long term information preservation. As the information on computer distributed continues to grow, the need for better security measure arises. The society has become dependent on computer applications, web services and networked systems. In Hong Kong, Researchers have discovered that a single gram of bacteria is capable of holding more information than a 900TB hard drive. Storing information in bacteria and other living organisms becomes a more promising area for future preservation and security of information and is called biostorage which is also a growing field of interest for students at Hong Kong's Chinese University in which they made use of E. coli to test the limits of data storage.

Research in 2007 by a group of Japanese researchers showed that due to bacteria's ability to constantly reproduce, there is tendency for a group of these organisms to hold information for thousands of years. Students in Hong Kong are building on this previous research and were able to discover a way to condense data, store it by chunks in organisms and as well map the DNA to easily find the information at a later time. With this, the preservation and security of information for the future is assured

\subsection{RSULT AND ANALYSIS}

Data were analyzed as they related to the specific areas of the study using descriptive statistics such as frequency distributions, percentages and cross tabulation. 
International Journal of Advances in Scientific Research and Engineering (ijasre),Vol 5 (6), June-2019

Demographic Information of the Respondents

Table 1: Distribution of respondents by Length of Service

\begin{tabular}{|c|c|c|}
\hline Variable & Frequency & Percentage \% \\
\hline 10 years and below & 14 & 8.5 \\
\hline $11-20$ years & 17 & 10.3 \\
\hline $21-25$ years & 25 & 15.2 \\
\hline $26-30$ years & 32 & 19.4 \\
\hline $31-35$ years & 77 & 46.6 \\
\hline Total & 165 & 100 \\
\hline
\end{tabular}

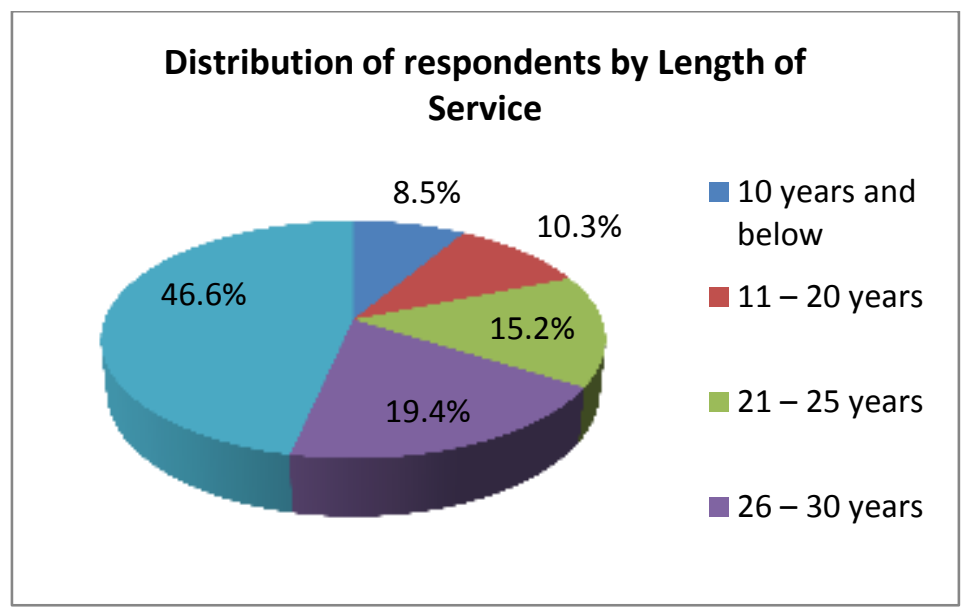

Fig.1 :Distribution of respondents by Length of Service.

The result in Table 1 and Fig. 1 indicates that 14(8.5\%) respondents were in service between 10years and below, 17(10.3\%) respondents were in service between 11-20 years, 25(15.2\%) respondents were in service between 21-25 years, 32(19.4\%) respondents were in service between 26-30 years and 77(46.6\%) respondent were in service between 31-35 years. It revealed that the highest respondents to the questions on preservation and security of information resources in selected institutions, organizations, libraries, archives and museums in Nigeria had spent up to or more than thirty-one (31) years in service as indicated by $77(46.6 \%)$ respondents.

\section{Research Questions:}

Research Question 1: What are the available information resources in the selected organizations?

Table 2: Available information resources in the selected organizations

\begin{tabular}{|c|c|c|c|c|c|}
\hline S/N & Variables & Yes & Percentage (\%) & No & Percentage (\%) \\
\hline 1 & Textbooks & 165 & 100 & - & - \\
\hline 2 & Fictions & 24 & 14.5 & 141 & 85.5 \\
\hline 3 & E-resourses & 153 & 92.7 & 12 & 7.3 \\
\hline 4 & Newspapers & 140 & 84.8 & 25 & 15.2 \\
\hline 5 & Journals & 24 & 14.5 & 141 & 85.5 \\
\hline 6 & $\begin{array}{c}\text { Audio-visual } \\
\text { resourses }\end{array}$ & 12 & 7.3 & 153 & 92.7 \\
\hline 7 & Reference resourses & 146 & 88.5 & 19 & 11.5 \\
\hline
\end{tabular}

From the table, it is shown that the least available information resources were audio-visual resources. 
Research Question 2: What policies exist on preservation and security of information resources in your organization?

Table 3: Existence of preservation and security policies on information resources

\begin{tabular}{|c|c|c|c|c|c|}
\hline S/N & Variables & Yes & $\begin{array}{c}\text { Percentage } \\
\text { \% }\end{array}$ & No & $\begin{array}{c}\text { Percentag } \\
\mathbf{e} \%\end{array}$ \\
\hline 1 & $\begin{array}{c}\text { Existence of } \\
\text { preservation policies }\end{array}$ & 106 & 64.2 & 59 & 35.8 \\
\hline 2 & $\begin{array}{c}\text { Usage of preservation } \\
\text { policies }\end{array}$ & 68 & 41.2 & 97 & 58.8 \\
\hline 3 & $\begin{array}{c}\text { Positive enhancement } \\
\text { of preservation } \\
\text { policies }\end{array}$ & 54 & 32.7 & 111 & 67.3 \\
\hline
\end{tabular}

Research Question 3: What is the level of support given by the management of your organization for the Preservation and security of information resources in their organizations?

Table 4: Levels of management support to preservation and security

\begin{tabular}{|l|l|l|l|}
\hline S/N & Variable & Frequency & Percentage \\
\hline 1 & Very high & 35 & 21.2 \\
\hline 2 & High & 100 & 60.6 \\
\hline 3 & Average & 21 & 12.7 \\
\hline 4 & Very low & 9 & 5.5 \\
\hline 5 & Low & - & - \\
\hline & Total & 165 & 100 \\
\hline
\end{tabular}

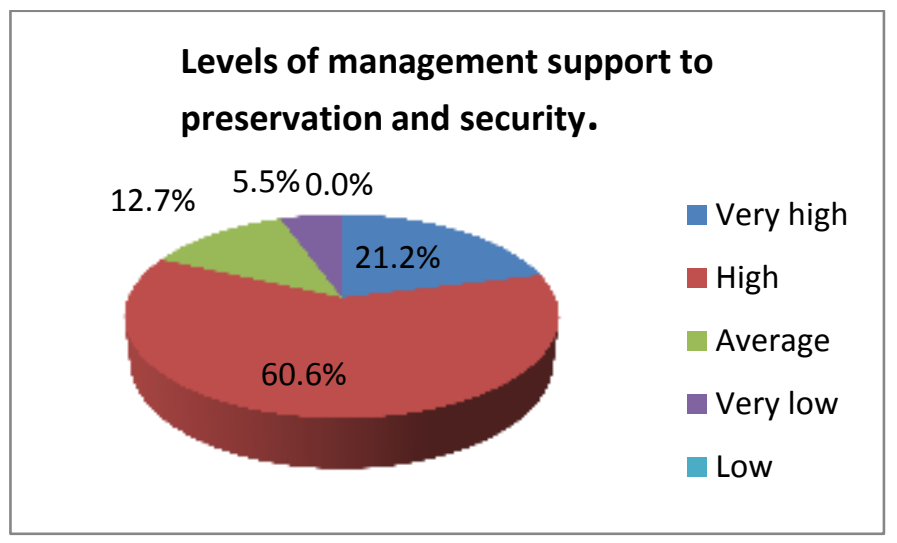

Fig. 2:Levels of management support to preservation and security.

Research Question 5: What are the barriers to effective preservation of information resources in your organization?

Table 6: Barriers to effective preservation of information resources

\begin{tabular}{|l|l|l|l|l|l|}
\hline S/N & Variable & $\begin{array}{l}\text { Strongly } \\
\text { Disagree }\end{array}$ & Disagree & $\begin{array}{l}\text { Strongly } \\
\text { Agree }\end{array}$ & Agree \\
\hline 1 & Inadequate funding & 45 & 5 & 60 & 55 \\
\hline 2 & $\begin{array}{l}\text { Lack of preservation } \\
\text { equipment }\end{array}$ & 15 & 25 & 63 & 62 \\
\hline 3 & $\begin{array}{l}\text { Management attitude towards } \\
\text { preservation }\end{array}$ & 89 & 35 & 25 & 16 \\
\hline 4 & $\begin{array}{l}\text { Lack of competent manpower } \\
\text { in preservation }\end{array}$ & 95 & 47 & 9 & 14 \\
\hline
\end{tabular}


International Journal of Advances in Scientific Research and Engineering (ijasre),Vol 5 (6), June-2019

\begin{tabular}{|l|l|l|l|l|l|}
\hline 5 & $\begin{array}{l}\text { Harsh environmental } \\
\text { condition }\end{array}$ & 90 & 42 & 21 & 12 \\
\hline 6 & Inadequate infrastructures & 25 & 27 & 29 & 84 \\
\hline 7 & Lack of preservation policy & 72 & 48 & 18 & 27 \\
\hline 8 & $\begin{array}{l}\text { Absence of e-equipment for } \\
\text { preservation e.g. computer } \\
\text { system, } \\
\text { scanning machine, } \\
\text { photocopier }\end{array}$ & 24 & 51 & 61 \\
\hline
\end{tabular}

Research Question 6: what is the level of protection offered to information resources in the past, today and in the near future?

Table 7: The level of protection to information resources

\begin{tabular}{|l|l|l|l|}
\hline Period & Past & Today & Future \\
\hline Percentage $\%$ & 19.5 & 31.1 & 49.4 \\
\hline level & Low & High & Very high \\
\hline
\end{tabular}

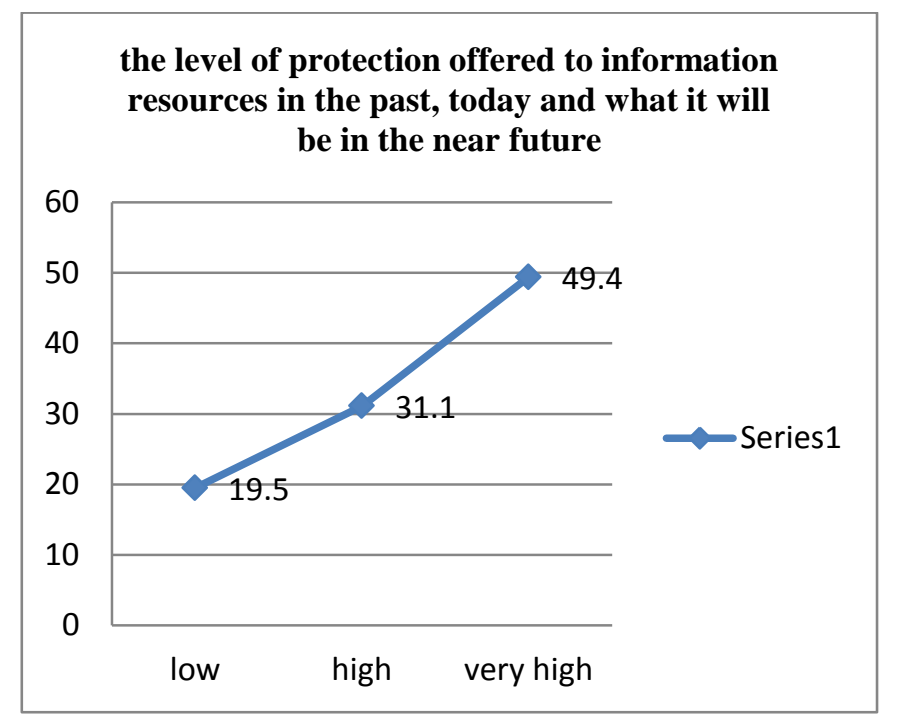

Fig. 3: Graph showing the level of protection offered to information resources in the past, today and what it will be in the near future

The result in table 7 and shown in Fig. 3 was gotten by taken the average inputs from the respondents to the question.

Research Question 7:Rate the level at which information is preserved in the past, today and what you think it will be in the near future?

Table8: The rate of preservation to information resources

\begin{tabular}{|l|l|l|l|}
\hline Period & Past & Today & Future \\
\hline Percentage \% & 11.4 & 35.2 & 53.4 \\
\hline Level & low & high & Very high \\
\hline
\end{tabular}




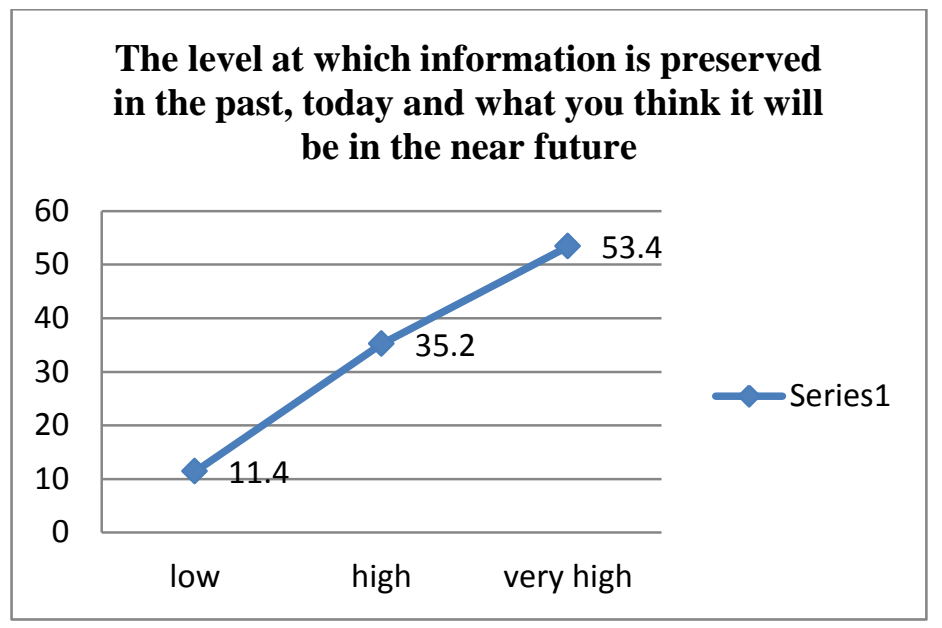

Fig. 4: Graph showing the level at which information is preserved in the past, what is like today and what it will be in the near future

The result in table 8 and shown in Fig. 4 was gotten by taken the average inputs from the respondents to the question.

Table 9: The average rating of the level at which information is preserved and secured in the past, what it is today and what it will be like in the near future.

\begin{tabular}{|l|l|l|l|}
\hline \multicolumn{1}{|c|}{ Period } & Past & Today & Future \\
\hline Percentage \% & 15.5 & 33.1 & 51.4 \\
\hline Level & low & high & Very high \\
\hline
\end{tabular}

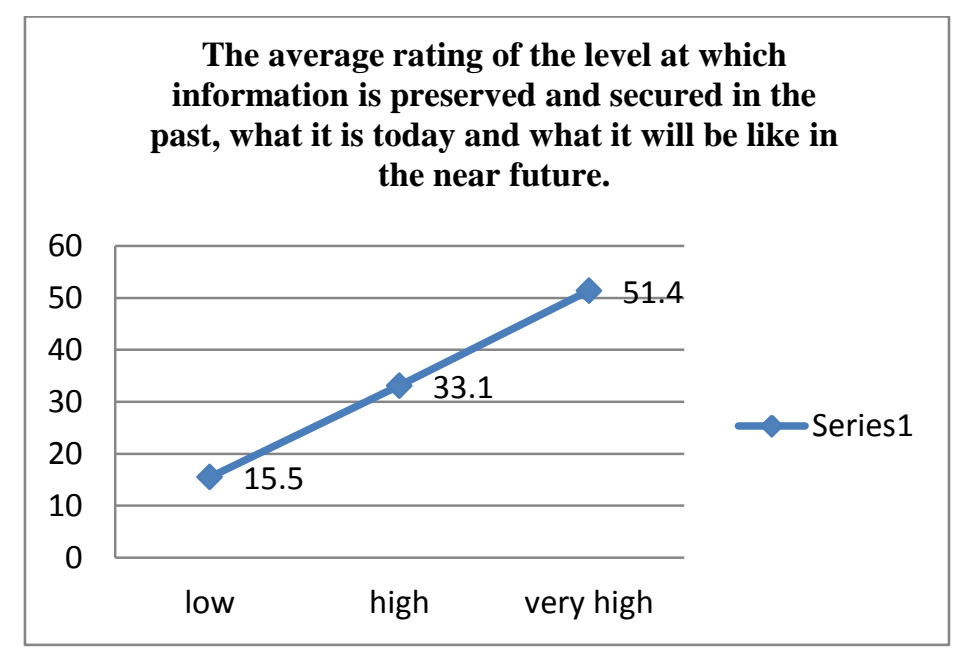

Fig. 5: Graph Showing the average rating of the level at which information is preserved and secured in the past, what it is today and what it will be like in the near future.

From the above analysis and results(TABLE 9), it is clear that both preservation and security of information and information resources suffered set back in the past, but with the evolution of ICT (information and communication technology) in which computers are been used, it has taken a new look today. Preserving and securing information is now better, efficient and more reliable today than in the past but the future will be much better.

\subsection{CONCLUSION}

Preservation and security is an essential aspect of information and information resources that cannot be left out. If handled properly, information is assured to last for ages and can be accessed anytime, any day with authorization. Based on the results of this research, it is seen that information preservation and security is on the progressive side. 
International Journal of Advances in Scientific Research and Engineering (ijasre),Vol 5 (6), June-2019

\section{REFERENCES}

1. Popoola, S.O., The status of records management in the state universities in Nigeria”. In: Babalola, J.B, Adedeji, S.O. (eds.) Contemporary Issues in Educational Management. Ibadan: The Department of Education Management, University of Ibadan., 2003.

2. Isah, E.E., Preservation of Digital Materials: The role of the Library" Zaria Journal of Librarianship .6. 1\&2, 2003, 1-10

3. Nwiyenwa, S., The Development of Archives in Africa. Problems and Prospects" in Wise Michael (ed.) Aspects of African Leadership, London: Mansell ., 2000, 258.

4. International Federation of Library Association (2003). Audiovisual and Multimedia Section Guidelines for Audiovisual and Multimedia Materials in Libraries Draft June 2003. Retrieved May 22, 2013

5. Matangira, V., Audiovisual Archiving in the Third World; Problems and Perspectives: An analysis of audiovisual archiving in the East and Southern African Region Branch of the International Council on Archives (ESARBICA). ESARBICA Journal 22, 2003, 43-49.

6. Thomas R.Peltier, Information Security Policies, Procedures and Standards, Guidelines for Effective Information Security Management, Auerbach Publications [2002], Pg.[31-32].

7. Gay, N.C., (1976). "The change of shape of a viscous ellipsoidal region embedded in a slowly deforming matrix having a different viscosity—a discussion”. Tectonophysics, 35(4), pp.403-407.

8. Gartner, Designing an Adaptive Security Architecture for Protection from Advanced Attacks” January 2016.

9. Isah, E.E., Preservation of Digital Materials: The role of the Library" Zaria Journal of Librarianship .6. 1\&2, 2003, 1-10

10. Vincent K. K., Using Image Steganography Technique to Obscure Information from unauthorized user , 2016 , pg 19 \& 27.

11. Mike Lynett, A History of Information Security From Past to Present" Posted on Nov 25, 2015 9:35:00 AM

12. Torsten George, The Past, Present, and Future Of Cyber Security" on November 30, 2016.

13. Digital Preservation Coalition, PDF should be used to preserve information for the future Added on 1 April 2008. 